\title{
THE DEVELOPMENT OF FUTURE EFL TEACHERS' INFORMATION COMPETENCE IN PROFESSIONAL TRAINING
}

\author{
Yana Bondaruk \\ Pavlo Tychyna Uman State Pedagogical University, Uman, Ukraine \\ bondaruk.yana@ukr.net
}

\begin{abstract}
The article explicates the significance of the development of future EFL teachers' information competence for their professional career and investigates the possibility to improve this competence in studying English. It also reveals the relations between information competence and professional development of future EFL teachers and proves that information competence has become the important one for life-long education of EFL teachers. It depicts that the information competence influences the professional level of future EFL teachers, their creative skills and abilities. In the article, compulsory and optional courses in the system of the teacher education for the development of information competence are analysed. It examines the importance of the use of information technology during professional training, as it solves not only the task to improve future EFL teachers' education but the development of the information competence of new generation school teachers. It proves that digital technologies influence the development of new ways of teaching and learning English, form new professional characteristics of EFL teachers; create new key competences for lifelong learning of future professionals. It deals with the problem that the lack of adequate access to the information and communication technology has the influence on the development of highly skilled professionals in the sphere of English language education.
\end{abstract}

Keywords: future EFL teachers; information technologies; communication; professional training; professional development; information competence.

\section{Introduction}

The modern world is placed on the verge of a real revolution that can change people's life fundamentally and substantially - their style of living, working, resting, as well as their philosophy of living in general. This process is called "information revolution". It means that the rapid development of information technologies deals with unlimited possibilities to use the fantastic achievements of science and technical devices everywhere. Informatization occupied every sphere of social activity: from daily routine to international relationships, from tourism to manufacturing relationships. Today we can observe the rapid technological change and proliferating information resources. The process of informatization has become an inevitable part of various spheres of vital activities in a digitised and networked world.

Under previously mentioned conditions, the necessity of transformation processes in the system of professional study and development of future EFL teachers arises. It is clear that a well-qualified EFL teacher of the 21 st century needs professional knowledge, skills and experience, and also should be ready to "recognise when information is needed and have the ability to locate, evaluate, and use effectively the needed information" (American Library Association, 2000, p. 2).

The present time requires the immediate solution of a set of educational problems connected with real demands of a labour market: youth preparation to new conditions of life, the formation of personal qualities according to the demands of the future profession, etc. However, we should admit that the development of information technologies causes the new model of the system of education when common methods and aims of studying should be changed. One of the urgent tasks of education is the formation of educational interests of future specialists, their intellectual and creative possibilities in professional work. The real way of approaching this problem is to form information competence of future EFL teachers who know the manner how to use modern hardware in professional work and can use effectively the information found with the help of the hardware.

In a recent study, Ferrari (2012) explained the role of information competence in the qualified experts' professional development. The researcher defines it as a set of knowledge, skills, and attitudes that are important to perform tasks; solve problems; communicate; manage information; collaborate; create and share content; and build knowledge effectively, efficiently, appropriately, critically, creatively, autonomously, flexibly, ethically, reflectively for work, leisure, participation, learning, socializing, consuming, and empowerment (pp. 3-4). It proves the importance of information competence for every EFL teacher. This competence is not only essential for simplifying teacher's work, but for expanding professional possibilities in today's digital world.

Information competence is often defined as basic skills in ICT required to use computers and to retrieve, assess, store, produce, present and exchange information, and to communicate (European Commission, 2008). It is also considered to be something that comprises a combination of a set of technical and 
procedural, cognitive, and socio-emotional skills which are necessary for living, learning, and working in a digital society (Cervera, 2015). A number of studies define that the notion of information competence is associated with computer literacy, digital competence, information culture, e-skills, technology training (Ferrari, Brečko, \& Punie, 2014; Cervera \& Cantabrana, 2015)

The aim of this study is to explain the importance to enhance information competence of future EFL teachers and to explicate the possibilities to develop it during the study of specialised disciplines in English.

\section{Limitations and liabilities of integrating information technologies into the professional development of future EFL teachers}

On the one hand, it is easy to form information competence of a modern student under the conditions of a rapid technological change having access to information technologies. On the other hand, there is a difficulty as a number of teacher preparation programs is focused on language knowledge development and the enhancement of foreign language skills. According to the globalisation processes in the world, knowledge and skills must be applied in new ways; the system of teachers' preparation should provide the coherence and cohesion between foreign language knowledge development, the enhancement of skills for the use of information, and presentation skills. As a result, the importance and necessity of new programs of teachers' preparation and their professional development, as well the development of new projects of information competence and literacy formation of educators have increased.

The European Commission's document "Rethinking Education" notes the importance of the reforming education and training systems. It invites to "... revise and strengthen the professional profile of all teaching professions..." According to the document, each stage of teaching career needs clearly defined competences and enhancing teacher's information competence (European Commission, 2012).

A good example of such program can be a Project "New Generation School Teacher" that was jointly initiated by the British Council Ukraine and the Ministry of Education and Science Ukraine and launched in March 2013. This project is focused on the changes to the initial teacher education system in Ukraine (British Council, 2016). One of the main tasks of the Project is to break traditionally fixed stereotypes about the role of a teacher in the educational process as a sender of the information. The teacher is ready to perform a new role - the organiser of the process of education (Transcarpathian In-service Teacher Training Institute, 2016). The members of the Joint Project are convinced that the understanding of the necessity and importance of skills for the use of information and communications technology in education is the key to success in the development and enhancement of teachers' professional skills and in their information and professional culture formation (British Council, 2016).

\section{The relations between future EFL teachers' information competence and their professional training}

Branekova (2015) considers that the quality of higher education, innovations and academic research form the "knowledge triangle" of every educator. In other words, experts, including EFL teachers, should be ready to work in the information society and be ready to modernise and transform professional knowledge and skills. In this case, information technologies offer a good opportunity for enhancing education quality and can create new approaches in education and training.

The digital technologies influence the educational tradition and types of teacher training programs. The European Commission's document "Key competences for lifelong learning" emphasises the importance of eight new competences for every educator's Life Long Learning: communication in a mother tongue; communication in a foreign language; scientific, technological literacy; information competence; learning to learn; interpersonal, civic competences; entrepreneurship; cultural expression (European Commission, 2007). As a result, all these competences can be considered essential to develop during the study of EFL teachers in a changing world.

As discussed by Ferrari, Brečko, and Punie (2014), information competence is a transversal key competence and it needs to acquire other key competences mentioned above. "Being digitally competent today implies the ability to understand media, to search for information and be critical about what is retrieved, and to be able to communicate with others using a variety of digital tools and applications. All these abilities belong to different disciplines and traditions" (p. 2). Authors are convinced that information competence is highly debated and can be presented in five different areas: information, communication, content creation, safety, problem-solving. We consider that all these identified areas relate to EFL teachers training and have a great influence on their professional competence (it is often considered as the combination of linguistic, discourse, sociolinguistic and strategic competencies (Jabu, 2015)). 
"Information" is the core of EFL teachers training. Today teachers and students deal more with digital information - they are capable of searching, filter and evaluate it for their personal and educational use. "Communication", as an area for information competence, is of equal importance with information. It helps teachers and students interact through digital devices, adapt communication modes to the levels of students' English, etc. The area of "content creation" is able to help EFL teachers to create different platforms for studying and knowledge with the help of technologies. The area of "safety" is due to protect EFL teachers and students from threats existing in the digital world. "Problem-solving" can be found in other areas, as it helps to identify and solve possible problems in teaching and learning English using digital means.

Thus, in today's technology rich world it is not enough for EFL teachers to have basic professional skills of reading, writing and speaking which effect the development of professional competence. Information competence has become one of the important needs for successful professional training and work.

\section{The information culture in the system of professional English language teacher education at Pavlo Tychyna Uman State Pedagogical University, Uman, Ukraine}

In modern bachelor's degree programs (6.020303 Linguistics. Language and Literature (English)) and master's degree programs (8.02030302 Language and Literature (English)), there is a list of special educational courses focused on information competence development of future EFL teachers. For instance, Pavlo Tychyna Uman State Pedagogical University (Pavlo Tychyna Uman State Pedagogical University, 2016) allows students to study Fundamentals of Information Science and PC, Information Technologies in Education and Science, Methods of Linguistic Research, Theory and Practice of Scientific-Pedagogical Investigations and others.

Fundamentals of Information Science and PC is a compulsory course in the curriculum of modern bachelor's degree programs and goes to develop skills to work effectively as a PC user using software of general and special purpose, to use a PC in local nets and the Internet. This course explores contemporary state of the level and tendencies of hardware development, principles of modern information technologies, structure and working principles PC components, principles of modern software functioning. (Pavlo Tychyna Uman State Pedagogical University, 2016). It is clear that this course must be an inevitable part of teacher preparation programs as it plays the great role in the development of eight new competences of future EFL teachers.

Information Technologies in Education and Science course is also compulsory in master's degree programs. This course examines the subject and basic notions of IT used in education and science; explores the role of the Internet, the use of text and table processors in education and science; teaches to use presentation programs. Future EFL teachers have the possibility to explore the current state of the development of IT, the fundamentals of modern information technologies in education and science. Besides, this course helps to develop special skills to use the PC applying modern IT technologies, to realise the main elements of software used in education and science, to develop the teacher's portfolio (Pavlo Tychyna Uman State Pedagogical University, 2016). It goes without saying that these skills are increasingly important for a well-qualified EFL teacher of the 21st century.

Theory and Practice of Scientific and Pedagogical Investigations course is compulsory. One of the main parts of its content is information support of scientific research. This course must enhance students' skills to choose the problem of scientific research; to formulate scientific apparatus; to organise the procedure of pedagogical research; to choose the best research methodology; to design research results in accordance with the scientific work (Pavlo Tychyna Uman State Pedagogical University, 2016). The whole list of the skills mentioned above helps to develop information competence that is a part of key competences for lifelong learning of future EFL teachers.

Creative Technology in Higher Education course helps students to examine the peculiarities of creative technology in education, different types of creative technology, theory and practice of the use of problembased learning, project-based learning, differentiation, and individualization. Students develop skills of the use of creative technologies in education (Pavlo Tychyna Uman State Pedagogical University, 2016).

Methods of Linguistic Research, as an optional course, can also be considered as the essential part of master's degree program. It helps to form the information culture of future EFL teachers and to develop knowledge of modern methods to collect and process the needed information. Students enhance their skills in presenting information on the course correctly, logically, consecutively and concisely. The content of the course includes general methods to collect and analyse the information (Pavlo Tychyna Uman State Pedagogical University, 2016). It is obvious, that such kinds of studying promote the development of students' information competence and, of course, have an impact on the study of specialised disciplines in English. 
It is necessary to emphasise that not only the educational courses (compulsory and optional) provide the integration of educational media and educational technologies into professional training and development of future teachers and form information competence of educators during their professional career. Camacho (2006) believed that "the world witnesses the rapid flow of ideas and knowledge through the information highway". As a result, this "highway" reinforces the impact of information technology in all spheres of people's life. Education is not the exclusion in this case. Information competence (or information literacy) of teachers has become an integral part of their professional life. New and newer technologies have changed the style and process of education. They suggest new ways of teaching, new roles of teachers, new styles to develop professional competence.

\section{The use of modern forms of educational media and educational technologies in compulsory practical courses in English}

Teachers and students can influence the development and adoption of information technologies. For this reason, both educators and students should understand the use of the technologies, benefits and inevitability of the integration into different aspects of educators' activities, the importance and the potential of information competence for their future professional career.

Bachelor's degree programs and master's degree programs allow students to study compulsory practical courses (English Practice, English Grammar in Theory and Practice, etc.) and to develop and enhance their professional skills. However, these courses can also play an important role in the formation of future EFL teacher's information competence. In this case, different modern forms and methods of educational media and educational technology can be used.

The use of e-mail and social networks as Facebook, Twitter helps to solve the task to study English and it creates the situation of the professional communication using educational media and educational technology.

Video hosting services (YouTube, VK, Facebook, My Video, Yahoo! Video, etc.) help to enhance skills of choosing and using multimedia materials in education and to develop skills and experience of professional interaction using educational media and educational technologies.

Learning platforms (Popplet, Glogster, Canva-Graphic Design and Photo Editing, Infogr.am and others) help students create and share infographics, charts, and other types of data illustration; create online posters that contain text, images, and multimedia elements; organise information, color-code topics, type in data, and add comments (Common Sense Education, 2016). The use of different learning platforms in English teacher education programs gives a good opportunity to form information literacy; it improves students' creative skills and their desire to be engaged in continuing professional development.

Video and audio editing is one of the most difficult tools of media educational technology. Its use needs special skills. Georgiadi (2013) has found that creative skills of the use of video and audio editing will help to extend the content of professional courses. These skills have the great "capabilities" for foreign language teacher professional preparation. Such an approach proves that this method of the use of media educational technologies in English teacher education programs helps to develop information competence.

Judging by our own experience, the presentations of various projects using the program of Microsoft PowerPoint (Ovadiuk, 2015) are also effective. It is helpful during the final lessons of various thematic modules. The project-oriented learning is quite effective, active and engaged. Students obtain a deeper knowledge of the subjects they're studying, they use information communications technologies to prepare projects, they are engaged in the process of formation of their information culture. The practice of the use of PowerPoint presentation increases the chances to use enhanced skills in the future professional development of EFL teacher.

The use of the online learning Platform Moodle (short for "modular object-oriented dynamic learning environment") for English teacher training can be considered as a good way to enhance information culture of students. This system of online education is widely used in universities of higher education (National University "Lviv Polytechnic", Pavlo Tychyna Uman State Pedagogical University, Cherkasy State Technological University and others) and promotes the effective organisation of interaction between teachers and students. This platform is used in over 234 countries that speak 80 languages (Moodle, 2016). It has a great number of functions, which can help to improve students' skills and knowledge of the use of media and educational technology in education and in the future professional career.

Teachers' and students' own Web sites and blogs improve the process of future teacher's preparation. This method gives a good opportunity for students' self-studying, and a chance for enhancing skills of the use of information technologies, as well as it promotes the formation of information competence. 
Researchers provide important insights into preparing EFL teachers to use technologies in their daily work. According to Swenson, Rozema, Young, McGrail, \& Whitin's (2005), new technologies are sure to change "the types of texts we and our students create and interpret even as they are influencing the social, political, and cultural contexts in which our texts are composed and shared" (p. 211). It is the natural consequence of the globalisation, which requires significant changes in the system of teacher education; we witness the intensification of demands upon highly skilled professionals who are proficient in not only English but also information technology. There is a growing awareness of the need for students to become more digitally literate (Bikowski, 2014). A well-qualified professional has to know and be able to use enhanced skills and knowledge in his professional work; he must be up to the requirements of the digital world; he should "...become content producers, not just consumers, as technology is integrated into curricula" (NCERT, 2005).

But still some problems exists. Not every student has access to information technologies. Swenson, Rozema, Young, McGrail, \& Whitin's (2005) findings prove that “... preparing English educators to model effective integration of technology into their teaching will be of little use if their students and their students' students don't have adequate access to those technologies" (p. 218). But Thomas Friedman (2005), in his bestseller, "The World is Flat", analyses globalisation and notices that, we live in the world when collaboration and competition in real time with different people on various kinds of work on real equal footing are possible than ever. It is because of new information and communication technologies that are always dynamic and influence the professional and private life of every person all over the world even if he does not have "adequate access to those Technologies".

\section{Conclusions}

The formation of information competence, as one of the key competences for the professional career of future EFL teachers, is an increasingly important task for a modern system of professional preparation and development of a well-qualified educator of the 21st century. Today in the global world, it is impossible to isolate the system of English language teacher education and say that this system does not undergo changes in information and communication technologies. The information competence influences the professional level of the future EFL teachers, their creative skills and abilities. Students should gain experience of the use of the information technology and share their knowledge with each other, as it will help to organise continuing professional development in the future. It has been found that compulsory and optional courses (Fundamentals of Information Science and PC, Information Technologies in Education and Science, Methods of Linguistic Research, Theory and Practice of Scientific-Pedagogical Investigations), as well as compulsory practical courses (English Practice, English Grammar in Theory and Practice) play the important role in the formation of information competence in the system of English language teacher education. The use of modern forms and methods of educational media and educational technologies (e-mails, social networks, video hosting services, learning platforms, video and audio editing, presentations and projects using the program of Microsoft PowerPoint, online learning Platform Moodle, teachers' and students' own Web sites and blogs) in compulsory practical courses provides the solution not only the task to improve EFL teachers' training but the formation of the information competence of new generation school teacher.

This study does not cover all features of information competence in the system of EFL teachers' education. The role of distance education and online tests of future EFL teachers, the use of cloud computing in English language teacher education require further study and investigations.

\section{References:}

American Library Association. (2000). The Information Literacy Competency Standards for Higher Education. Chicago, Illinois. Retrieved July 14, 2016 from http://www.ala.org/acrl/standards/informationliteracycompetency

Bikowski, D. (2014). The Pedagogy of Collaboration: teaching effectively within an evolving technology landscape. In Pickering, G. and Gunashekar, P. (Eds.), Selected papers from the fourth International Teacher Educator Conference "Innovation in English Language Teacher Education" (pp.223-232). Hyderabad, India.

British Council. (2016). New Generation School Teacher. Joint Project of the British Council Ukraine and the Ministry of Education and Science Ukraine. Retrieved July 14, 2016, from http://ngschoolteacher.wix.com/ngscht

Camacho, Jr. \& Jose D.V., (2006, October). Skill Formation and the Knowledge Economy: Some Issues and Problems in the Philippines. $6^{\text {th }}$ Economic Conference on Business and Economics. Gutman Conference Center, USA.

Cervera, M.G., Cantabrana, J. L. (2015). Professional development in teacher digital competence and improving school quality from the teachers' perspective: a case study. New approaches in educational research, 4 (2), 115-122. https://doi.org/10.7821/naer.2015.7.123

Common Sense Education (2016). Apps and Websites for Making Posters. Retrieved June 28, 2016, from https://www.commonsense.org/education/top-picks/apps-and-websites-for-making-posters

European Commission. (2008, November 30 - December 2). Digital Literacy European Commission Working Paper and Recommendations from Digital Literacy High-Level Expert Group. Report presented at E-inclusion Ministerial Conference \& Expo. Vienna, Austria. 
European Commission. (2007). Key competences for lifelong learning: European reference framework. Luxembourg: Office for Official Publications of the European Communities.

European Commission. (2012). Rethinking Education: Investing in skills for better socio-economic outcomes. Strasbourg, COM, $669 / 3$.

Ferrari, A. (2012). Digital competence in practice: An analysis of frameworks. Seville: European Commission, Joint Research Centre, Institute for Prospective Technological Studies.

Ferrari, A. (2013). DIGCOMP: a Framework for Developing and Understanding Digital Competence in Europe. Luxembourg: Publications Office of the European Union.

Friedman, T. (2005). The World is flat: A brief history of the twenty-first century. New York: Farrow, Straus \& Giroux.

Georgiadi, O. A. (2013). Peculiarities of future teachers-philologist education using modern educational media and educational technology. Vcheni zapysky Tavriys'koho natsional'noho universytetu im.V.Vernads'koho. Problems of Secondary and Higher Education, 26 (65), 140-150.

Jabu, B. (2015). The Problems in Professional Competence of Teachers in Teaching English Subject at Vocational High Schools. ELT Worldwide, 2 (2), 95-109.

Moodle. (2016). Moodle Overview. Moodle is the open source platform that lets you build the perfect education solution for your needs. Retrieved July 15, 2016, from https://moodle.com/moodle-lms/

National Council of Educational Research and Training (NCERT). (2005). National Curriculum Framework, India. Retrieved September, 15 from http://www.ncert.nic.in/rightside/links/nc_framework.html

Ovadiuk, O. V. (2015). Innovative methods as an important part of learning foreign languages. Advanced Education. 4, 45-50.

Swenson, J., Rozema, R., Young, C. A., McGrail, E., \& Whitin, P. (2005). Beliefs about technology and the preparation of English teachers: Beginning the conversation. Contemporary Issues in Technology and Teacher Education, 5(3/4), 210-236.

Pavlo Tychyna Uman State Pedagogical University. (2016). Foreign Languages Department. Course Catalog. Retrieved July 10, 2016, from http://fld.udpu.org.ua/en/

Transcarpathian In-service Teacher Training Institute. (2016). Programy dlia vchyteliv angliyskoji movy [Programs for teachers of English]. Retrieved July 14, 2016, from http://zakinppo.org.ua/zagalni-novini/895-programi-dlja-vchiteliv-anglijskoyi$\underline{\text { movi }}$

Received: July 18, 2016

Accepted: March 26, 2017 